\title{
02. The Rise (and Fall?) of Transitional Gender Justice: A survey of the field
}

Lucy Fiske

lucy.fiske@uts.edu.au

\section{Introduction}

Gender justice has been a significant focus of political, legal, humanitarian and scholarly attention over the last twenty-five years. Prosecutions of sexual violence crimes at the International Criminal Tribunal for Rwanda (ICTR) and the International Criminal Tribunal for Yugoslavia (ICTY) were observed as 'ground breaking' (Askin 2003, 317) and many women's rights advocates and scholars wrote optimistically of the 'end of impunity' and of 'explosive' progress in bringing the effects of war and armed conflict on women in from the margins to be central concerns in peace negotiations, transitional justice processes and post conflict development (Duffy and Dicker 1999; Eaton 2004; Schomburg and Peterson 2007). Greater gender awareness in international criminal law has been matched by increased attention in international politics and post-conflict development priorities, with actors in all arenas expressing commitment to improving gender justice in conflict and postconflict situations. Notable actions include UN Security Council Resolution 1325 (2000) and several subsequent resolutions, the raising of the 'women, peace and security' agenda to high-level status, targeting aid and development programs to women and girls and, much expanded media coverage of women in conflict zones. The optimism with which these developments were initially greeted however, has given way to a growing recognition that, despite the greater attention to gender in all these fields, the lives of women in conflict and post-conflict settings have changed little (Pankhurst 2008; Alam 2014).

This chapter first sets out a broad survey of key developments in transitional gender justice post World War Two (with much greater focus on post-ICTR and ICTY) and then moves to a survey of major standpoints on the capacity of transitional justice to transform the lives of women. Given the extensive developments in the field of transitional justice a comprehensive account is beyond the scope of this work. Instead, this chapter will focus on some key moments in the development of gender justice in the last 70 years in order to establish a map of the terrain within which the subsequent chapters of this book stand. 


\section{Developments in transitional gender justice}

Some scholars trace transitional justice to 1945 with the end of World War Two and the decision to try Axis leaders for war crimes under a form of international law (Teitel 2003, 70; Chesterman 1997), while others locate transitional justice's origins in the late 1980s and early 1990s with transitions from authoritarian to democratic rule in Eastern Europe and Central America (Bell 2009, 7; Arthur 2009). In this chapter I use Teitel's (2003) three phase genealogy of transitional justice: postWW2 and the Cold War; the 1980s and early 1990s; and post-ICTR and ICTY, as a framework for organising the developments in the field.

At the opening of the Nuremburg Trials in November 1945 US Chief of Counsel, Justice Robert H. Jackson noted the exceptionality of the Allies' decision to try senior Nazi leaders as 'one of the most significant tributes that Power ever has paid to Reason' (cited in Chesterman 1997, 299). Teitel $(2003,72-3)$ notes that the Nuremberg Trials marked at least two important foundations for future phases of transitional justice - firstly, the use of international rather than national law in pursuit of accountability, and secondly, seeking to apply international criminal law to individuals rather than states. While the models developed at Nuremberg and Tokyo had significant limitations and have been criticised as 'victor's justice' (Nagy 2014, 221), they nonetheless marked a significant normative shift that established key roles for international society and the application of international criminal law following crimes committed during times of war (Teitel 2003).

The onset of the Cold War and the decades long stand-off between the USA and the Soviet bloc ensured a period of stasis in the development of international criminal law ${ }^{1}$. The collapse of the Soviet Union in the late 1980s caused significant power shifts around the globe. Many regimes, previously supported by the Soviet Union or enabled by the geopolitics of the Cold War era collapsed. Some, such as Somalia (see Abdulkadir and Abdulkadir, chapter 13, this volume), descended in to civil wars as groups vied for power. Others, particularly in South and Central America and Eastern Europe, began transitioning from authoritarian to democratic rule. It was at this time that the term 'transitional justice' was first used (Bell 2009, 7). This postCold War context is important for understanding how transitional justice has developed in the years since then. Embedded within the term is a normative assumption that the 'transition' of 'transitional justice' is towards democratisation based on liberal individualism and a free market economy (Arthur 2009; Rees and 
Chinkin 2015, 1212; Teitel 2003, 75). Arthur $(2009,326)$ argues that the historical context (the triumph of liberal democratic capitalism) is critical in explaining 'why the measures of prosecutions, truth-telling, restitution, and reform of abusive state institutions - not some other measures of justice, such as those associated with claims for distributive justice - were recognized as the legitimate justice initiatives during a time of political change.' This liberal notion of justice has particular implications for gender justice, and is discussed further later in this chapter.

The period throughout the 1980s and early 1990s enabled the development of transitional justice as a field of both scholarship and practice, drawing together a range of techniques and strategies under a single umbrella explicitly aimed at normative objectives of democratisation, nation-building, promulgation of the rule of law and, economic development following free-market models (Rees and Chinkin 2015, 1012). This period saw significant exchange of ideas and experiences between emerging democracies in the Global South through several conferences and visiting delegations (Arthur 2009; Bell 2009). Despite the relatively high degree of sharing between states undergoing political transitions, Teitel $(2003,76)$ notes a high degree of sovereign autonomy in determining what sort of transitional justice would be implemented in each case. Argentina launched domestic prosecutions of former military junta leaders and held the first truth commission: the National Commission on the Disappeared (Sikkink 2011). Peru followed a similar model, holding the Comisión de la verdad y Reconciliación (see Macher chapter 12, this volume), prosecuting the leaders of both the Shining Path and former governments, launching a national reparations program and wrestling with how the conflict will be remembered (see Boesten chapter 9, this volume). Post-Soviet states in Eastern Europe tended not to hold truth commissions or prosecutions, but focused more on institutional reform, dismantling intrusive secret police and opening up the archives for truth seeking, giving a more prominent role to historians in the establishment of history rather than the quasi-judicial truth and reconciliation commission model (Arthur 2009).

Thus, this second phase of transitional justice development expanded its focus beyond the 'holding to account' of the post-WWII prosecutions to include forward looking concerns of nation-building (Teitel 2003, 76-77). These whole of society concerns drew in complex and highly contingent political, legal and social considerations in deciding what sort of transitional justice mechanisms would be most likely to advance the nation-building project. The different types of harms that men 
and women faced, and the gendered nature of both direct and structural violence was rarely, if ever, a focus in the transitional justice initiatives of this period in either Eastern Europe or Central or South America. The co-existence of silence on gendered harms and concern with nation-building is unlikely to be coincidental. Periods of heightened nationalism or attention to nation-building are almost invariably marked by a heightening of conservative and essentialised gender roles and norms (Cockburn 1999; Yuval-Davis 1993, 627; Fiske and Shackel 2014, 128-129) while simultaneously, all parties (those formerly engaged in direct conflict and the international community) can find commonality in patriarchal frameworks and logics (Ní Aoláin 2009, 1057). The complementary patriarchies of national and international actors converged to ensure that the violence and human rights violations targeted in transitional justice was largely political violence suffered by men, while the types of violence more commonly experienced by women was seen as 'ordinary' (and therefore falling within the domain of ordinary national systems) and excluded from transitional justice processes (Bunch 1990; Ní Aoláin 2009, 1059; Nagy 2014, 225).

The third phase of transitional justice began in the mid 1990s with the establishment of the International Criminal Tribunals for Rwanda (ICTR) and Yugoslavia (ICTY). This phase saw a return to the use of international law and universal jurisdiction for war crimes and crimes against humanity, alongside a marked increase in high level political attention to women's experiences in conflict and postconflict societies and a significant expansion of humanitarian aid and development. The field of transitional justice has expanded enormously in the last 25 years and has 'now moved from the periphery to the center' (Teitel 2003, 89) such that 'the question today is not whether something should be done after atrocity, but how it should be done' (Nagy 2014, 216).

\section{Legal/Prosecutorial developments}

The ICTR and ICTY played critical roles in the development of international jurisprudence on war crimes and crimes against humanity, much of which has informed the Rome Statute (1998) which established the International Criminal Court (ICC). Both tribunals prosecuted sexual violence, establishing important jurisprudence about the use of sexual violence in war and, establishing the foundations for sexual violence to be a central concern for the third (and current) phase of transitional justice's development. The first conviction for sexual violence 
was handed down by the ICTR in September 1998 against Jean-Paul Akayesu, former Mayor of Taba commune in Rwanda. The Akayesu ${ }^{2}$ decision was critical in several respects: it was the first conviction under international criminal law for sexual violence, it found that rape was used in the Rwandan genocide as a widespread and deliberate tactic and constituted both genocide and a crime against humanity, it found that circumstances of conflict and mass violence are coercive (removing arguments around consent) and, finally, Akayesu was not accused of committing any rapes himself, but for sending 'a clear signal of official tolerance for sexual violence, without which these acts would not have taken place. ${ }^{3}$ The ICTY extended the principle of superior responsibility to recognise that conflict and mass violence create a high risk environment for sexual violence, and therefore officers have a positive onus to proactively investigate 'in order to ascertain whether offences were being committed. $^{4}$

The establishment of the ICTR and ICTY was followed by several hybrid courts and tribunals including the Special Court for Sierra Leone, the Serious Crimes panels in Timor Leste, the Extraordinary Chamber in Cambodia and, the Bosnian War Crimes Chamber. Following the ratification of the Rome Statute (1998) by the requisite number of countries, the ICC opened on 1 July 2002 and, at the time of writing, lists 24 cases ( 5 currently at trial), 10 situations under investigation and 10 preliminary investigations (ICC 2017, 1). In March 2016, the ICC handed down its first conviction for sexual crimes, against Jean-Pierre Bemba, a Commander of the Movement for the Liberation of Congo (MLC) for crimes committed in Central African Republic (ICC 2017, 3) (for more on ICC prosecutions see Shackel chapter 10 , this volume).

The inclusion of sexual violence at the highest levels of transitional justice was hailed by women's rights activists as a victory for human rights in general and for women's rights in particular, bringing to an end the 'age of impunity' (Eaton 2004; HRW et al 2014). Kelly Askin $(2003,288)$ noted that 'laws prohibiting wartime sexual violence languished ignored for centuries' and the successful prosecution of rape, sexual slavery and other forms of sexual violence by the ICTR and ICTY 'is unparalleled in history and has established critical precedential authority for redressing these crimes.'

\section{Truth Commissions}


The early truth commissions in Argentina, Peru, South Africa and Guatemala did not explicitly include gendered harm in their terms of reference, limiting the commissions' scope to fulsomely capture and address the effects of those regimes and conflicts on women. The South African Truth and Reconciliation Commission in particular has been subject to significant critique of its ad hoc approach to gendered harm, particularly in its focus on political crimes and exclusion of both ordinary and structural violence and, its hearing from women principally as witnesses to the violence committed against men, which had lasting implications for the historical record of the effects of apartheid, the distribution of reparations and other key policy and justice interventions (Borer 2009; Kusafuka 2009; Goldblatt and Meintjes 1996). The Commission acknowledged these shortcomings in its final report stating 'that it would have to "amend its understanding of its mandate and how it defined gross human rights violations" to "integrate gender fully" and that " the Commission's relative neglect of the effects of the "ordinary" workings of apartheid has a gender bias"” (Kusafuka 2009, 60-61). Later truth commissions in East Timor, Sierra Leone and Haiti included a focus on gender explicitly in their mandates and sought to proactively uncover the gendered ways in which violence and oppression functioned both directly and indirectly (Bell and O'Rourke 2007, 28). Nonetheless, in each of these cases, sexual violence against women is centralised while other harms such as physical violence, disinheritance, displacement and exclusion are given less attention.

The Sierra Leone Truth and Reconciliation Commission's report has a standalone chapter on women's experiences of the violence and developed gender-sensitive methodologies for the Commission's engagement with women. It proactively sought their participation, provided counselling and material support for women testifying before the commission and allowed women to choose whether to give written or oral testimony, and whether to testify at an open or closed hearing. The Commission trained specialised women statement takers to work with women affected by sexual violence. The Commission's report explains that, while 'women are not explicitly mentioned in the TRC Act' (SLTRC 2004, 86), the Commission's mandate to 'afford "special attention to the subject of sexual abuse", (SLTRC 2004, 86) required it to look specifically at the experiences of women and girls during the conflict. While sexual violence was the enabling term of reference, the Commission determined 'to capture the experiences of both women and girls in respect of sexual violence, as well as their complete gendered experiences at a political, legal, health and social welfare 
level' (SLTRC 2004, 87). Indeed, the Report's chapter on women spends some considerable time on locating women historically, politically, economically and socioculturally in Sierra Leonean society prior to the conflict seeking to understand the contexts that may have contributed to the particular types of violence committed. While the chapter addresses some non-sexual violence that women experienced (such as amputations, displacement and killings) its major focus is nonetheless on a disturbingly broad range of sexual crimes committed against Sierra Leonean women during the conflict.

A significant criticism of both prosecutions and truth commissions is their narrow focus on sexual violence and lack of attention to the wide range of complex and intersecting harms that women face during and after war. Grewal (2015) argues that women's inclusion in high level transitional justice processes has overwhelmingly been achieved on the basis of their status as victims of sexual violence, a focus that works against the larger political project of equality.

\section{Politico-legal developments/Treaties and resolutions}

The increased focus on serious gender-based crimes committed during conflict or during authoritarian regimes is produced by a paradigm shift at the highest levels, one which has also produced changes in the political and legal context in which transitional justice mechanisms operate. In 2000 the UN Security Council passed Resolution 1325, a legally binding document aimed at ensuring conflict, peace building and post-conflict reconstruction processes would keep gendered violence and gender inequality as central concerns in design and implementation (Shepherd 2011, 505). While the Resolution has been criticised for reproducing essentialised and conservative gender stereotypes (women as 'natural' peace-makers, vulnerable and in need of protection and, men as aggressors - see for example Shepherd 2011), the specific focus on women in conflict at the highest level was nonetheless both an important development and an indication of the success of women's rights advocates at getting their concerns 'on the agenda.' UNSCR 1325 has been followed by several subsequent Resolutions progressing the 'Women, Peace and Security' (WPS) Agenda particularly focusing on recognition of sexual violence as a war crime, crime against humanity and an element of genocide, the urgent need to stop sexual violence in conflict, the need to improve women's participation in peace processes, and for 
gender to be incorporated into all post-conflict development programs (PeaceWomen n.d.).

As in prosecutions and truth commissions, WPS Resolutions disproportionately focus on sexual violence against women with too little attention to the complex interrelationships of gender, poverty and violence. While later Resolutions do note the need to ensure aid and development programs reach women, there is little substantive articulation of the ways in which poverty and the disproportionate work burdens borne by women act as barriers to their effective participation in political processes.

Despite several resolutions affirming women's right to participation in peace processes, women's participation remains 'strikingly low' (UN Women 2012, 1) with women comprising just nine per cent of peace negotiation delegations and only four per cent of signatories to peace agreements globally since UNSCR 1325 in 2000 (UN Women 2012, 2). Bell and O'Rourke (2007, 24-25) argue that wars and peace negotiations remain predominantly male affairs with high stakes (political power, amnesty, prosecutions, territory and more) and that even if women manage to get a seat at the table, they continue to struggle to get women's concerns addressed in these negotiations. McWilliams and Kilmurray $(2015,128)$ report that of the 585 peace agreements signed since 1990 only sixteen per cent contain 'at least one reference to women and gender.'

Women's exclusion from peace negotiations is not due to either an 'absence of women's demands for accountability' (Bell and O'Rourke 2007, 25) or to women's lack of interest or experience in peace negotiations (UN Women 2012, 26). Christine Chinkin and Kate Paradine (2001) analysed the 1995 Dayton Agreement which brought an end to the Bosnia war. Women's civil society groups actively argued for inclusion of women's political participation, violence against women, prostitution and trafficking in the agreement. None of which were addressed in the Dayton Agreement. UN Women report that women have pushed hard for involvement in peace processes in many countries around the world, often holding parallel peace forums, 'not by choice or design, but as a reaction to women's exclusion from the official peace talks' (UN Women 2012, 10).

Women have organised and mobilised to insist upon input, if not formal participation, in peace processes in Somalia, Kenya, Uganda, Libya, Liberia, Indonesia and other conflicts around the globe. In Indonesia, women in Aceh held the 
All Acehnese Women's Congress in 2000 and again in 2005 seeking input into peace negotiations. The Uganda Women's Peace Coalition (UWPC) formed a Women's Peace Caravan in 2006 and drove from Kampala to Juba (South Sudan) where peace talks between the Lord's Resistance Army (LRA) and Government of Uganda were being held. They managed to get observer status in the peace negotiations, but when these talks collapsed, the UWPC was not invited when the talks resumed in 2008. The All Party Burundi Women's Peace Conference (2000) stood in the hallways outside the negotiating room and lobbied negotiators, advisors and donors as they entered or exited. In Liberia, the Mano River Women's Peace Network and the Women in Peacebuilding Program managed to attain observer status in negotiations to end that conflict - but did not have voting or speaking rights. They found greater impact through their activism; staging sit-ins and ultimately barricading negotiators in, refusing to allow anyone to leave the building until the peace agreement was signed (UN Women 2012, 9 - 10).

UN Security Council Resolutions, world leaders' stated support for women's involvement in peace negotiations and women's determined and creative efforts have not yet translated to greater participation by women in these high stakes negotiations.

\section{Key Critiques and Discussion}

An increasing number of scholars are now beginning to acknowledge that despite the remarkable expansion and normalisation of transitional justice processes, the transitional justice project has led 'ultimately to ambivalent consequences' (Teitel 2003, 90), and that 'overall there is little evidence that there has been comprehensive "success"” (Rees and Chinkin 2016, 1213). The increased concern about gender justice and gender equality has delivered similarly ambivalent results. Kelly Askin, having optimistically written of the 'extraordinary progress made in ... redressing gender-related crimes' $(2003,346)$ in 2003, concluded a speech delivered in Sydney in July 2015 by saying that 'after 25 years working on these issues I have more questions than answers [and] more frustration than hope' (2015). It seems that some significant rethinking is required if transitional justice processes are to reach their promised potential of substantively improving women's access to justice and equality in post-conflict societies.

\section{Persistent problems}


Transitional justice's focus on a specific historical moment - the period and processes of transition from war or an authoritarian regime to peace and democratic rule - and its distinction between 'extraordinary' and 'ordinary' violence creates a range of significant difficulties for women. In many unhelpful ways, this binary structuring replicates rather than challenges the public-private divide that sits at the foundation of liberal democratic politics and law (Bunch 1990; Rao 2001). It also imports many of the structural barriers that impair women's access to justice, equality and rights.

While women's rights activists lauded the prosecution of sexual violence committed during war and hoped that this would bring an end to impunity and build a pathway for the continuum of violence that women face in both peace and war to be recognised and addressed, several scholars make powerful arguments that the ways in which International Criminal Law (ICL) has framed sexual violence reinforces sexual violence in conflict as 'exceptional' and thereby strengthens profoundly harmful tropes about sexual violence committed under 'ordinary' circumstances (Grewal 2015; Campbell 2004). Sexual violence is not a crime in its own right under ICL, but must be committed in particular circumstances in order to constitute a war crime, crime against humanity or genocide (Chesterman 1997; Grewal 2010). This requirement displaces a woman's experience from central to marginal in the definition and understanding of sexual violence - transitional justice mechanisms do not address rapes of women by peace-keepers, by men from their own ethnic group, by humanitarian actors or in other circumstances falling outside the definitions contained in ICL. Chesterman $(1997,332)$ argues that 'the legal response to rape in war' rests on 'the effacement of the feminine subject, and her selective appropriation into the discourse of war crimes as the bearer of essentialised feminine virtues.' The raped woman only appears in ICL as the witness to the offence committed against the group, not against herself.

The current legal construction of rape as a war crime, crime against humanity or genocide reinforces women's status as the symbolic bearers of nation and honour and, in doing so, reinforces one of the key logics that underpins rape's power as a weapon of war - that by raping 'their women' one side can demoralise, dishonor and emasculate the enemy. Not only does this risk heightening women's vulnerability to the very attacks it seeks to redress, but it affirms damaging cultural or religious beliefs regarding a woman's chastity or 'purity' that stigmatise women as somehow sullied 
and of little or no value after rape (Askin 2003, 298; Fiske and Shackel 2015, 112). In this way ICL continues rather than challenges historical constructions of women not as autonomous rights-bearing subjects, but as representatives (and reproducers) of nation and bearers of the group's honour (Fiske and Shackel 2014, 132, 128).

Grewal $(2015,151)$ extends this critique, pointing out that not only is the woman victim-survivor moved to the margins, but that the requirement of specific contexts for rape to become a crime under international law leads to arguments that perversely normalise or downgrade 'ordinary' rape, making the wider feminist struggle to end sexual violence against women in all circumstances that much harder: 'while there are clearly jurisdictional questions about whether an act is a domestic or international crime, this has all too often become confused with identifying a qualitative difference in the nature of the act in question.'

Women's rights scholars and activists had hoped that gender sensitive transitional justice processes would help establish new norms for prosecuting sexual violence within national legal systems, through for example, the recognition of situations as coercive and the prohibition of introducing a victim's sexual history as a defense (Spees 2003). There is little evidence however, that any of the progressive developments internationally have been incorporated into any national justice systems, but rather, that the international system has adopted a number of problematic aspects of national systems (Grewal 2010), aspects which work against potential therapeutic gains through testifying in a supportive environment with issues of a victim's sexual conduct or prospective consent removed. This can be seen in particular when looking closely at transcripts in trials in which the prosecution's need to elicit key facts to establish elements of the crime, and the defense's need to destabilise this evidence, all too often replicates the traumas of domestic rape prosecutions (Henry 2009). Campbell (2004) and Nikolić-Ristanović found similar troubling trends in their (separate) analyses of ICTY trials with Nikolić-Ristanović concluding that '...by finding evidence of rape camps and yet finding that individual women are not to be believed in their accounts of rape and violence at those same camps, the Yugoslav Tribunal reproduces many of the same problematic aspects of the rape trial found in Western domestic legal systems' (cited in Grewal 2010, 68).

Even at truth commissions, where prosecutions are not sought, similar patterns can be observed. Despite truth commissions' claims to 'the healing potential of storytelling, of revealing the truth before a respectful audience and to an official 
body' (South African TRC Report cited in Henry 2009, 117), there is little supporting empirical evidence (Laplante and Theidon 2007, 237). Kusafuka (2009, 52-53) shares an excerpt from the Special Women's Hearing in Johannesburg during the South African TRC in which the commissioners repeatedly ask the witness, a survivor of sexual violence, why the perpetrator raped her:

CHAIRPERSON: But he was not doing that in a political context, he was just doing it as a man who wanted to do that to you as a person? I am trying to get that clarity.

$[\ldots]$

CHAIRPERSON: Again, I would like us to be clear on this. So, this man wanted to rape you not because it was a, there was no political context. He was just doing it, because he is use [sic] to doing that.

MS MXATHULE: The riots were not yet over in Jubatine at that time. We were still involved in the political struggle.

MS SEROKE: [a debriefer]: Maria, we want you to assist us to have the political context of the first story you told us about. You heard that Sheila Meintjies during her submission here, she said that at some of the days, there is a very thin line between domestic violence and political violence ... did he do this [rape] because he knew you were a Comrade or he just did it because he wanted to have sex with you?

In parallel with judicial processes, truth commissions can all too easily replicate the focus on establishing certain contextualising aspects of an episode, overlooking the individual's experience of violence and the therapeutic benefit of having editorial control over the retelling of that violence. Laplante and Theidon (2007) argue that, in order to deliver on their healing promises, truth commissions need to be carefully structured, not only in how testimony is heard (they report that all participants in their study found the process of testifying cathartic and of benefit), but also in linking truth commissions with redress mechanisms.

The mechanisms of redress desired will vary between different situations, often reflecting the socioeconomic, cultural and political status of victim-survivors. Laplante and Theidon $(2007,243)$ point to the different justice desires of Argentina's mothers of the disappeared who refused offers of compensation preferring criminal prosecutions, and the rural women of Peru who saw reparations as an essential 
component of justice: 'Among the rural poor, demands for justice are overwhelmingly expressed in an economic idiom: the struggle to survive results in practical considerations such as the need for farm animals, suitable housing, or education for their children.' Whichever forms of redress (prosecutions, reparations, institutional reform, memorialisation or more) are desired, it is critically important that truth commissions have redress mechanisms attached to them and that the state takes concrete steps to implement the commission's recommendations, failure to do so risks further eroding public/victim-survivor confidence in the state thereby undermining a key goal of transitional justice.

\section{Widening the lens for women-centered justice}

Transitional justice's separation of 'ordinary' and 'extraordinary' violence has supported a rather narrow focus on sexual violence as the principal harm that women endure during conflict, often obscuring the many ways in which women are affected by war. Transitional justice mechanisms and processes 'ignore a much wider range of institutional and structural elements that may cause greater harms to society as a whole and to women in particular' (Ní Aoláin 2009, 1064). For many women, the distinction between political violence and ordinary violence that transitional justice makes, is not reflected in their lived experience. Fiske and Shackel $(2015,67)$ report that many women in northern Uganda drew strong analogies between the war violence and the current ongoing violence in homes and communities, citing one woman as saying that 'when one is still experiencing a lot of violence, [it] does not qualify as peace.' It is not uncommon for there to be an increase in violence against women after the cessation of war (Ni Aolin 2009, 1064; Bell and O'Rourke 2007, 43), and while this violence shapes women's daily lives, it falls beyond the purview of transitional justice mechanisms. Transitional justice's demarcation of types of violence, elevating concern around violence deemed capable or likely of destabilising nascent peace or emerging political and rule of law institutions, while ignoring the continuum of violence identified by women in post-conflict societies, exposes a particularly narrow (and state-centric) conception of 'justice'.

The tightly focused lens of transitional justice too often relegates the injustices and forms of possible redress identified by women in a great many post-conflict societies to something outside its jurisdiction. Wars very often leave a significant number of women widowed, many at a young age, and subject to a range of harms 
resulting from this social status including: being dispossessed of land and other property (Shackel and Fiske 2016, 41-2), exclusion from social and public life (Yadav 2016), vulnerability to further violence (Sabri et al 2016), wife inheritance (Schütte 2014) and extreme poverty. While some of these harms, such as the poverty resulting from losing an income-earning husband, are a direct consequence of widowhood, most are products of gendered social relations that see women's value as dependent upon male relatives. An examination of the injustices excluded from transitional justice processes reveals much about its historical and political roots. As argued by Paige Arthur $(2009,326)$, the model of justice envisioned by transitional justice is a liberal capitalist one and excludes distributive and social justice demands, perhaps seeing these as matters for the national democratic process to attend to in the fullness of time. Fiona Ní Aoláin $(2009,1057,1059)$ sees the exclusion of the wide range of justice claims made by women as arising from the 'complimentary patriarchies that are evidenced between local and international actors' and which work together to define security and justice in a masculinist and state-centric manner.

\section{Where to from here?}

Even this brief survey of some feminist critiques of transitional justice's failure to substantively change the lives of women in post-authoritarian and postconflict societies, leads to questions about transitional justice's capacity to respond to women's justice claims in transitional societies. Some scholars advocate a reformist path - improve institutions and processes to make them more gender-sensitive and woman-friendly.

Rees and Chinkin $(2016,1211,1213,1225)$ argue that transitional justice 'has become an industry', leading to its application in a 'formulaic approach' at the expense of substantive participation by 'those who did not take up arms and who have knowledge of what is needed at the community level to end conflict.' Rosemary Nagy (2014, 216, 226) expresses similar concerns about transitional justice as a 'global project' with 'troubling features of its standardisation' and delivered by a highly mobile 'professional body of international donors, practitioners and researchers'; a cluster of institutions and individuals far removed from 'ordinary people's lives' and unlikely to bring substantive change to those lives. All three advocate for international actors and local elites to make much greater space for substantive participation by 'ordinary' people, including women and girls directly affected by the conflict. 
Through greater participation 'victims ... gain a sense of agency that may, in and of itself, be an important form of rehabilitation, especially when victims come to perceive themselves as actors of social change' (Rees and Chinkin 2015, 1224). The participation of non-elite women, all three scholars contend, ought to result in a broadening of transitional justice's scope to better encompass economic, social and cultural rights (Rees and Chinkin 2015, 1219; Nagy 2014, 224), a need identified by a great many scholars (see for example Laplante and Theidon 2007; Goldblatt and Meintjes 1996).

Linked to the need for increased participation, but exposing conundrums that run much deeper than which justice demands ought to be included in transitional justice, is the charge of coloniality. "International law is "brought" to war-torn countries' (Nagy 2014, 217) by the international community, dominated by the wealthier, more powerful and predominantly former colonial powers, raising questions around: To whose vision is society transitioning? What are legitimate goals and temporal limits for international involvement? And what effects does the involvement of the international (and better resourced) community have on local justice initiatives? The Acholi people of northern Uganda have expressed significant ambivalence about the ICC's indictment of LRA commanders (Branch 2017) and there is emerging evidence that tensions are being exacerbated by the current trial of Dominic Ongwen (JRP 2016; Fiske and Shackel 2016, 146-7). While survivorvictims can participate in international trials (as witnesses or observers) and in programs delivered by the international community, to what extent can their participation influence the decision-making and direction of such initiatives?

Several empirical studies highlight the centrality of distributive justice to the justice claims of women (and men) living in poverty (Laplante and Theidon 2007; Fiske and Shackel 2016; Rees and Chinkin 2015). While transitional justice incorporates reparations, and many humanitarian and development programs accompany transitional justice initiatives, international and national actors could do more to address structural social and economic injustices (or better support local communities in their efforts to address these concerns).

Fiona Ní Aoláin sees transitional justice as a field that needs to radically expand its territory if it is to recognise the justice needs of women and begin to break down the patriarchal compact that enables both international and national legal and political systems to continue defining security and justice in a state-centric, masculine 
manner. Transitions, she argues, need to broaden to include 'gendered transformations necessary to genuine social revolution' (Ní Aoláin 2009, 1085).

While Nagy (2014) and Ní Aoláin (2009) called for radical, or at least structural, change, others argue, whether implicitly or explicitly, that women's justice energies might be better placed in local initiatives where decision-making control is locally held. Almost a decade ago Scully (2009) asked 'should (women) give up on the state?' and, concluded, as she does in her contribution to this volume, that nonstate based initiatives often have much greater space for women's agency to define justice for themselves and work towards attaining those justice goals. Whereas the contribution by Grewal (chapter five this volume) still sees significant value in institutional and high level transitional justice mechanisms, but in their co-option by local women's groups for use in ways never intended by their designers. Grewal relates the creative ways in which women have taken decisions made by the Special Court of Sierra Leone and use them to further their justice claims at the local level.

Gender injustice has deep roots and is proving extremely difficult to shift even with concerted attention at the highest international levels, women's justice claims continue to be relegated to secondary priority, women continue to be defined in terms of their sexual identities and reproductive abilities, and, despite multiple resolutions affirming their rights, continue to be excluded from important decisionmaking processes. Such persistent roadblocks open the possibility of terminal decline and the risk that the momentum behind the transitional gender justice project may be lost. To arrest such a fall reformist, expansionist, radical and community-based solutions are possible but it seems likely that they will need to be worked at, with creativity and determination, for some time yet.

\section{References}

Alam, Mayesha. 2014. Women and Transitional Justice: Progress and Persistent Challenges in Retributive and Restorative Processes. Basingstoke: Palgrave Macmillan. 
Askin, Kelly D. 2003. "Prosecuting Wartime Rape and Other Gender- Related Crimes under International Law: Extraordinary Advances, Enduring Obstacles.” Berkeley Journal of International Law 21 (2): 288-349.

Askin, Kelly D. 2015. "Post conflict Gender Justice - extraordinary attention, extra and ordinary lack of Progress" keynote speech delivered at Gender, Poverty and Violence: Implications for gender justice in post-conflict settings. A global symposium. Sydney 13 July. http://sydney.edu.au/law/events/2015/Jul/post_conflict_gender justice_13 July2015. $\underline{\mathrm{mp} 3}$.

Arthur, Paige. 2009. 'How 'Transitions' Reshaped Human Rights: A Conceptual History of Transitional Justice.” Human Rights Quarterly 31 (2): 321-367.

Bell, Christine. 2009. "Transitional Justice, Interdisciplinarity and the State of the 'Field' or 'Non-Field'.” International Journal of Transitional Justice 3 (1): 5-27.

Bell, Christine and Catherine O'Rourke. 2007. "Does Feminism Need a Theory of Transitional Justice? An Introductory Essay.” International Journal of Transitional Justice 1 (1): 23-44.

Borer, Tristan A. 2009. "Gendered War and Gendered Peace: Truth commissions and post-conflict gender violence: Lessons from South Africa." Violence Against Women 15: 1169-1193.

Branch, Adam. 2017. "Dominic Ongwen on Trial: The ICC's African dilemmas." International Journal of Transitional Justice 11 (1): 30-49. 10.1093/ijtj/ijw027.

Bunch, Charlotte. 1990. “Women’s Rights as Human Rights: Towards a re-vision of human rights." Human Rights Quarterly 12 (4): 486-498.

Campbell, Kirsten. 2004. "The Trauma of Justice: Sexual Violence, Crimes against Humanity and the International Criminal Tribunal for the former Yugoslavia." Social \& Legal Studies 13 (3): 329-350. 
Chesterman, Simon. 1997. "Never Again ... and Again: Law, Order, and the Gender of War Crimes in Bosnia and Beyond." Yale Journal of International Law 22 (2): 299-343.

Chinkin, Christine and Kate Paradine. 2001. "Vision and Reality: Democracy and citizenship of women in the Dayton Peace Accords." Yale Journal of International Law 26 (1): 103-178.

Cockburn, Cynthia. 1999. "Gender, Armed Conflict and Political Violence" presented at Gender, Armed Conflict and Political Violence, The World Bank, Washington DC, June 10-11.

Duffy, Helen and Richard Dicker. 1999. "National Courts and the ICC.” Brown Journal of World Affairs 6 (1): 53-64.

Eaton, Shana. 2004. "Sierra Leone: The proving ground for prosecuting rape as a war crime." Georgetown Journal of International Law 35 (4): 873-919.

Fiske, Lucy and Rita Shackel, R. 2014. "Ending Rape in War: How Far Have We Come?” Cosmopolitan Civil Societies Journal 6 (3): 123-138.

Fiske, Lucy and Rita Shackel. 2015. "Gender, Poverty and Violence: Transitional justice responses to converging processes of domination of women in eastern DRC, northern Uganda and Kenya.” Women’s Studies International Forum 51: 110-117.

Fiske, Lucy and Rita Shackel. 2016. Making Justice Work for Women. Uganda Country Report. Sydney: University of Sydney. https://opus.lib.uts.edu.au/handle/10453/71661

Goldblatt, Beth and Sheila Meintjes. 1996. "Gender and the Truth and Reconciliation Commission.” Indicator South Africa: Crime and Conflict no.6 (Winter): 5-8. 
Grewal, Kiran. 2010. "Rape in Conflict, Rape in Peace: Questioning the Revolutionary Potential of International Criminal Justice for Women's Human Rights.” The Australian Feminist Law Journal 33 (1): 57-79.

Grewal, Kiran. 2015. “International Criminal Law as Site for Enhancing Women's Rights? Challenges, possibilities, strategies." Feminist Legal Studies 23 (2): 149-165.

Henry, Nicola. 2009. "Witness to rape: The limits and potential of international war crimes trials for victims of wartime sexual violence." International Journal of Transitional Justice 3 (1): 114-134. http://dx.doi.org/10.1093/ijtj/ijn036.

Human Rights Watch (HRW), REDRESS, FIDH, TRIAL, ECCHR, Amnesty International. 2014. Investigating and prosecuting sexual and gender-based violence as crimes under international law. Open Letter to the EU Genocide Network on Investigating and Prosecuting Sexual and Gender-Based Violence as Crimes under International Law. 16 May 2014.

http://www.hrw.org/news/2014/05/16/lettermembers-eu-genocide-networkinvestigating-and-prosecuting-sexual-and-gender-b. Accessed 16 December 2014.

International Criminal Court (ICC). 2017. The Court Today, ICC-PIDS-TCT-01083/17_Eng Updated: 25 April 2017. https://www.icccpi.int/iccdocs/PIDS/publications/TheCourtTodayEng.pdf Accessed 12 August 2017.

Kusafuka, Ayumi. 2009. "Truth commissions and gender: A South African case study." African Journal on Conflict Resolution 9 (2): 45-67.

Laplante, Lisa and Kimberly Theidon. 2007. "Truth with Consequences: Justice and Reparations in Post-Truth Commission Peru.” Human Rights Quarterly 29 (1): 228250.

McWilliams, Monica and Avila Kilmurray. 2015. "From the global to the local: Grounding UNSCR 1325 on women, peace and security in post conflict policy making." Women’s Studies International Forum 51: 128-135. 
Nagy, Rosemary. 2014. "Transitional Justice as Global Project: Critical Reflections." in Law in Transition, edited by Ruth Buchanan and Peer Zumbansen, 215-226.

London: Bloomsbury Publishing.

Ní Aoláin, Fiona. 2009. "Women, Security and the Patriarchy of Internationalized Transitional Justice.” Human Rights Quarterly 31 (4): 1055-1085.

Pankhurst, Donna. 2008. Gendered Peace: Women's Struggles for Post-War Justice and Reconciliation. Abingdon: Routledge

PeaceWomen (n.d.) “About Women, Peace and Security in the Security Council." http://www.peacewomen.org/security-council/WPS-in-SC-Council Accessed 12 August 2017

Rao, Arati. 2001. "Right in the Home: Feminist theoretical perspectives on international human rights" in The Philosophy of Human Rights, edited by Patrick Hayden, 505-525. St Paul: Paragon House.

Rees, Madeleine and Christine Chinkin. 2015. "Exposing the Gendered Myth of Post Conflict Transition: The Transformative Power of Economic and Social Rights." New York University Journal of International Law and Politics 48: 1211-1226.

Sabri, Bushra, Shrutika Sabarwal, Michele R. Decker, Abina Shrestha, Kunda Sharma, Lily Thapa, Pamela J. Surkan. 2016. "Violence Against Widows in Nepal. Experiences, Coping Behaviors, and Barriers in Seeking Help.” Journal of Interpersonal Violence 31 (9): 1744-1766.

Shackel, Rita and Lucy Fiske. 2016. Making Justice Work for Women. Kenya Country Report. Sydney: Sydney University. https://opus.lib.uts.edu.au/handle/10453/71660.

Schomburg, Wolfgang and Ines Peterson. 2007. "Genuine Consent to Sexual Violence Under International Criminal Law.” The American Journal of International Law 101 (1): 121-140. 
Schütte, Stefan. 2014. "Living with patriarchy and poverty: women's agency and the spatialities of gender relations in Afghanistan.” Gender, Place \& Culture 21 (9): 1176-1192.

Scully, Pamela. 2009. "Should we give up on the State? Feminist theory, African gender history and transitional justice." African Journal of Conflict Resolution 9 (2): 29-43. http://dx.doi.org/10.4314/ajcr.v9i2.52171.

Shepherd, Laura J. 2011 "Sex, Security and Superhero(in)es: From 1325 to 1820 and Beyond.” International Feminist Journal of Politics 13 (4): 504-521.

Sierra Leone Truth and Reconciliation Commission (SLTRC). 2004. Witness to Truth. Report of the Sierra Leone Truth and Reconciliation Commission. http://www.sierraleonetrc.org/index.php/view-the-final-report Accessed 13 July 2017.

Sikkink, Kathryn. 2011. The Justice Cascade. How human rights prosecutions are changing world politics. New York: W \& W Norton.

Spees, Pam. 2003. "Women's Advocacy in the Creation of the International Criminal Court: Changing the Landscapes of Justice and Power." Signs: Journal of Women in Culture \& Society 28 (4): 1233-1254.

Teitel, Ruti G. 2003. “Transitional Justice Genealogy.” Harvard Human Rights Journal 16: 69-94.

UN Women. 2012. Women's Participation in Peace Negotiations: Connections between Presence and Influence. $2^{\text {nd }}$ Edition, UN Women, New York. Available: http://www.unwomen.org/ /media/headquarters/attachments/sections/library/publicati ons/2012/10/wpssourcebook-03a-womenpeacenegotiations-en.pdf Accessed 18 July 2017.

Yadav, Punam. 2016. Social Transformation in Post-conflict Nepal. A gender perspective. Abingdon: Routledge. 
Yuval-Davis, N. 1993. "Gender and nation.” Ethnic and Racial Studies 16 (4): 621632.

\footnotetext{
${ }^{1}$ While there is broad acceptance of this argument in the literature (see for example Teitel 2003, Grewal 2010) Paige Arthur (2009) mounts a persuasive argument that this narrative inaccurately truncates a much longer history and that colonial powers have a shared and active interest in maintaining either a post-Nuremberg or post-Cold War focus in order to exclude imperialism and the violence, oppression and exploitation inherent in colonialism from the current enthusiasm for 'dealing with the past.'

${ }^{2}$ Prosecutor v. Akayesu, Judgment, Case No. ICTR-96-4-T, 2 September 1998.

${ }^{3}$ Akayesu Judgment at para 693.

${ }^{4}$ Prosecutor v. Naser Oric (Trial Judgement). Case No. IT-03-68-T. 30 June 2006 at para 322.
} 